\title{
E-commerce and Competitiveness of the Bulgarian Trade Sector
}

\author{
Assoc. Prof. Violeta Dimitrova PhD \\ University of Economics - Varna, Varna, Bulgaria \\ violeta_dimitrova@ue-varna.bg
}

\begin{abstract}
Digitalisation in trading processes is one of the main sources of economic growth. Retail and wholesale trade are significantly and directly affected by the ongoing process, the dynamics of which increased in the conditions of economic crisis and Covid-19 pandemic. This study aims to make a comparative analysis of the trade sector in Bulgaria in comparison with the European countries, Central and Eastern Europe in particular, for the period after the 2008 economic crisis until the onset of the current crisis. We carried out a descriptive analysis by key economic indicators such as sales growth, e-GDP, gross margin of goods of resales, and labour productivity. We used mainly Eurostat data for the trade sectors according to the Statistical classification of economic activities in the European Community, as well as some date from the National Statistical Institute of Bulgaria (NSI).
\end{abstract}

Keywords: trade sector competitiveness, e-commerce, digitalization, retailing, wholesaling, gross margin

JEL Code: L81, M21 DOI: https://doi.org/10.36997/IJUSV-ESS/2020.9.3.3

\section{Introduction}

E-commerce and the digitalisation of trade processes lead to a reduction in the role of the trade area of retail outlets, 'tyranny' of the geography or the region (Couclelis, 2004) as experts define it. However, regional differences remain essential. Retail, wholesale, and international trade have a direct impact on the economic development of regions. Their main characteristics, such as territorial scope and political borders, shared cultural heritage, and significant intra-regional trade, are taken into account when defining the regions. This determines the importance of sectoral regional analyses, which are not only part of the assessment of the competitiveness of national economies but are also an essential element of competitive strategic planning for enterprises.

Trade as an economic sector is characterised by high dynamics, increasing competition, the introduction of new technologies and redesign of trade operations, changes in consumer behaviour, mutual penetration of online and offline trade and building an omnichannel environment, the emergence of new commercial formats, and the complexity of the supply chain. This paper focuses on e-commerce as a significant source of economic growth. Trade challenges affect not only the overall structure of the industry but also local communities. Trade sector has a substantial impact on other economic sectors throughout domestic consumption, exports, investments in information and communication technologies (ICT), trade infrastructure, logistics and transport services. The United Nations Department of Economics and Social Affairs (2020) calls on governments in developing and less developed countries to focus on advancing innovative and specific measures to address the challenges and adverse effects of digitalisation, by managing access to technology, employment and social exclusion, to achieve sustainable development.

The expansion of electronic communication and digitalisation deepens specialisation. The share of information and telecommunications services increases taking over all or part of traditional distribution functions (Betancourt, 2017) such as: location (access to a point of sale), selection and presentation of range, information, delivery (the share of so-called 'soft' products is expanding, some physical products being digitised included). Evolutionary changes of exchange in the context of digitalisation increase the necessity of sales regulation of digital services and goods. A draft law on the supply of digital content and digital services and the sale of goods is currently under discussion in Bulgaria.

This points to the need for regional analyses of competitiveness and productivity of trade sectors in the digital environment. 


\section{Need for research on competitiveness in the retail and wholesale sector}

Studies on the competitiveness of a product or an enterprise have been made for a long time. In recent years, there has been a significant increase in research and methodologies for regional competitiveness assessment, be it at countries, regions or settlements (mainly cities). Within trade as an economic activity, mostly foreign trade has been competitively assessed. Competitive analyses of particular economic sectors such as retail and wholesale trade are relatively limited compared to the indicated levels of studies. Trade policy, retail and wholesale, is only part of the activities of the Economic Policy Directorate at the Ministry of Economy.

Sectoral competitiveness studies, EU trade sector included, as well as other countries' economies, have made their way in recent years, our research demonstrates. In 2013, for example, the European Commission adopted a new European Retail Action Plan, taking into account the role of the wholesale and retail services sector in the EU economy in general in stimulating growth and jobs in line with the Europe 2020 strategy.

A European Commission's report (2015) examines the competitiveness of retail and understandably focuses on SMEs. Unlike the large international e-commerce companies operating worldwide, investing in new information and communication technologies and thus increasing efficiency, SMEs have limited access to finance. Investing in digital technologies is costly, SMEs lack visibility in the digital world and knowledge to implement innovations.

Productivity is a common goal and result of economic competitiveness in a particular economic sector. Understanding the changes in productivity in the distribution industry on the part of digitalisation is vital for understanding the evolutionary processes in retail and wholesale trade and its competitiveness as an economic sector.

The 2007 financial crisis prompted interest in more extensive research on the productivity of various economic sectors, including issues related to low labour productivity. Most analysis results show that job losses are not as high as expected, but real incomes have fallen, and post-crisis recovery has not worked out as expected. While productivity has increased over time historically, after 2010, it was characterised by retention or weak growth with fluctuations. The phenomenon produced the so-called "productivity puzzle" (Office for National Statistics, UK, 2015) exemplified by low levels of investment, decreased willingness of banks to lend to businesses as an impact of the financial crisis, increased number of people working after retirement due to changes in the age structure of the population and pensions, staff retention caused by low wage growth, etc. European Commission report (2020) defines 'e-commerce sector is a bridge between the digitisation of our society and the transition to a more sustainable economy'.

\section{Methodology}

This study does not claim to be complete or definitive. It focuses on key indicators assessing market attractiveness of the trade sector for investment: growth in sales revenue, e-GDP, gross margin, labour input and productivity. The market growth rate is a key indicator of investment attractiveness and competitive intensity (Porter, 1998). Gross value added (GVA) measures trade contribution as an economic sector to GDP, and supply chain intermediation as a key indicator of market power.

Gross margin is a micro-level mark indicating the result of commercial activity. It represents the value of trade service and is quantified as the difference between sales revenue and the cost of goods sold. Issues in measuring GVA as a productivity metric complicate productivity assessment of retail as an economic section. Unlike goods and some services, where costs of production and distribution are clearly separable (the separability of functions allows the production activity to be separated from the distribution activity), in the digital economy, the production, distribution and consumption of all of the distribution services themselves take place independently across time and space. There is a type II separability, with 'no physical or accounting limitation in outsourcing the 
distribution activity' (Betancourt et al., 2016). Calculating the gross margin of goods for resale or commercial revenue is complex with dependant variables: purchases of goods and services for resale in the same condition as received and changes in inventories of goods and services purchased for resale in the same condition.

Researchers (McKinsey \& Company, 2017) suggest the results of the digital economy to be measured mainly by ICT value added, e-commerce and household spending on digital equipment such as computers, tablets, smartphones, smartwatches and others. We performed a descriptive analysis of Eurostat data for the trade sector $(\mathrm{G})$, wholesale and retail trade according to the Statistical Classification of Economic Activities in the European Community. Additionally, we requested data from the National Statistical Institute (NSI) for Division G.47 Retail trade and for Class 47.91 - Retail sale via mail order houses or via Internet.

Competitiveness is a comparative category, which implies a comparison across trade sectors by countries. A major problem in comparative research is that the data sets in different countries may define categories differently. In view of historical developments, this study compares trade sectors in Bulgaria with their counterparts in Central and Eastern European countries, which made the transition to a market economy.

\section{Comparison of trade sectors: comparative analysis results}

Trade sectors by countries vary considerably depending on national market size and growth rate, domestic demand, income levels and propensity to consume, the relative share of wholesale trade, development and structure of foreign trade. Market growth is a crucial factor of competitive intensity, hence of return on investment too. Indices of the physical volume of sales in wholesale and retail trade $(2015=100 \%)$ in Bulgaria show low rate growth compared to some Central and Eastern European countries (Eurostat data for the period 2010 - 2019) (Figure 1). Slovenia, Romania and Lithuania exhibit the highest growth rates.

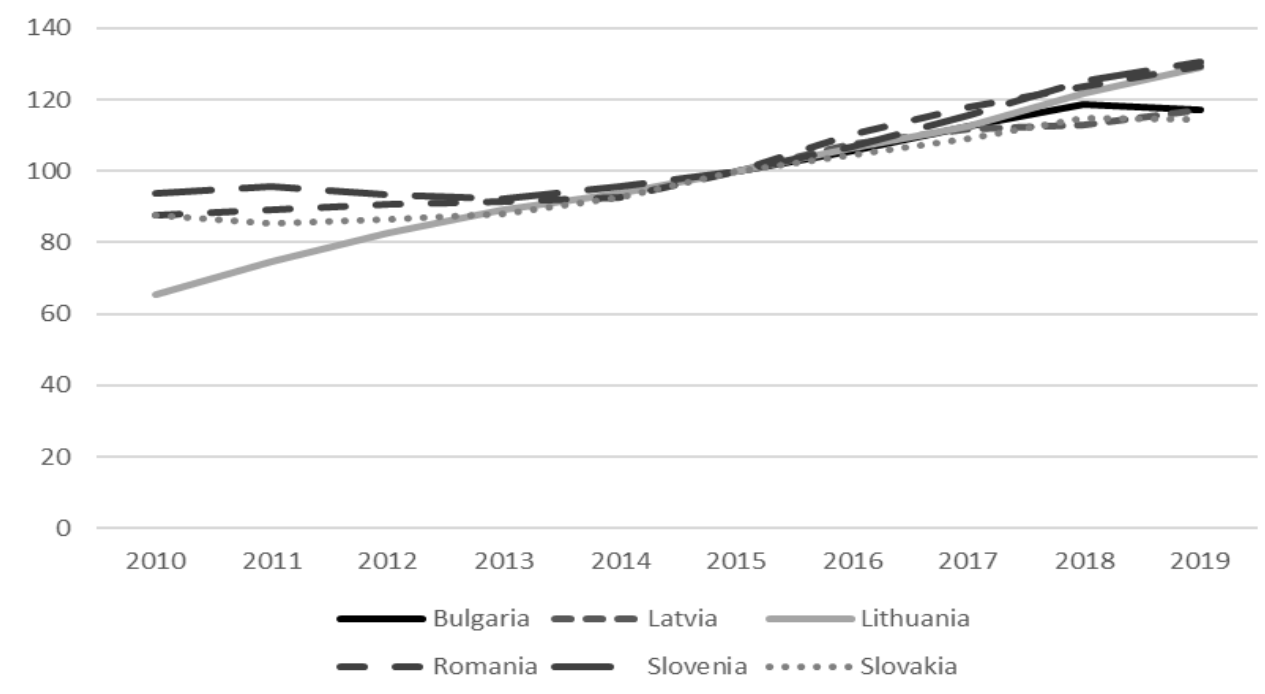

Figure 1. Sales in wholesale and retail trade by some

Central and Eastern Europe countries $(2015=100 \%)$

source: Eurostat and author's presentation

The wholesale and retail trade sector capacity is presented by the volume of sales and revenues, gross margin, the number of enterprises and employees. There is a decrease in the number of enterprises in the trade sector in the $27 \mathrm{EU}$ countries in general. In Bulgaria, the number of enterprises decreased most significantly in 2011, after which it increased slightly (2018 - 141 512) 
but did not reach the 2009 level (143 258). The situation in Slovakia is radically different from the general trend: the number of trade enterprises increased almost 4.5 times for the period, from 24 424 to 109243.

Sector concentration continued to rise during the period. In Europe, the number of enterprises with more than 250 employees is continually growing: from 7410 to 8070 , or with $8.91 \%$, while micro-enterprises with 2 to 9 employees are decreasing. In Bulgaria, we observe some dissimilarities compared to the general trend in Europe. The number of trade microenterprises with one employee only increased by $8.31 \%$ over the period, while microenterprises with 2 to 9 employees decreased by $10.85 \%$. Most significant is the decrease in the number of small enterprises with a staff of 20 to 50 people, whose number reduces by $13.55 \%$.

Table 1. Number of retail shops (NACE Rev.2, G47)

\begin{tabular}{|l|r|r|r|}
\hline countries & $\mathbf{2 0 1 2}$ & $\mathbf{2 0 1 7}$ & $\begin{array}{c}\mathbf{2 0 1 7 / 2 0 1 2} \\
\text { \% }\end{array}$ \\
\hline Bulgaria & 125909 & 112225 & 89,13 \\
\hline Croatia & 20239 & 19201 & 94,87 \\
\hline Lithuania & 15354 & 16326 & 106,33 \\
\hline Hungary & 114772 & 106591 & 92,87 \\
\hline Poland & 298816 & 55917 & 18,71 \\
\hline Romania & 111348 & 104411 & 93,77 \\
\hline Slovakia & 58195 & 18237 & 31,33 \\
\hline
\end{tabular}

source: Eurostat, National Statistical Institute of Bulgaria and author's calculations

Data for enterprises can be compared with data for retail outlets, which are generally declining by country. Eurostat statistical data are available, and the number of retail stores in 2012 and 2017 can be compared. For Bulgaria, we used the National Statistical Institute (NSI) data on the total number of stores. It should be noted that there is some difference in the data compared to those in Eurostat. The decrease is the largest in Poland and Slovakia (Table 1). Slovakia is the country with the highest commercial enterprise growth. This indirectly support the plausibility of the growing presence of ecommercial business.

These results should be compared with the number of registered e-shops, but statistics are not available. Until June 29, 2019, nearly 15000 e-shops have been reported in Bulgaria, according to press statements (profit.bg, 2019). The growth of retail e-sales is significant despite their meagre relative share in total sales, the widely used relative share indicator of e-sales in GDP (e-GDP). Problems related to the reporting of electronic sales should be pointed out. Only sales for which consumers have placed an order electronically via the Internet or by mobile phones are reported as electronic sales.

Trade sector development in recent years associated with the processes of digitalisation. Summary e-GDP data by regions in Europe for the period 2013 - 2019, according to Ecommerce Europe (2019) report in collaboration with EuroCommerce is presented on Figure 2. The differences between Western and Northern European countries and the countries of Central, Southern and Eastern Europe stand out, with the lowest relative share being encountered in the Eastern European countries in general.

Bulgaria (1.67\%) is in fourth place in terms of e-GDP among the sampled countries. The Czech Republic (2.95\%), Romania (2.42\%) and Poland (2.31\%) are ahead of it. However, Bulgaria stands out second with 30\% sales turnover growth for the period 2013 - 2019, along with Romania (30\%), following Estonia with e-commerce growth of 34.56\%. Data is presented on Figures 3 and 4, according to a report by Ecommerce Europe (2019) in collaboration with EuroCommerce. 


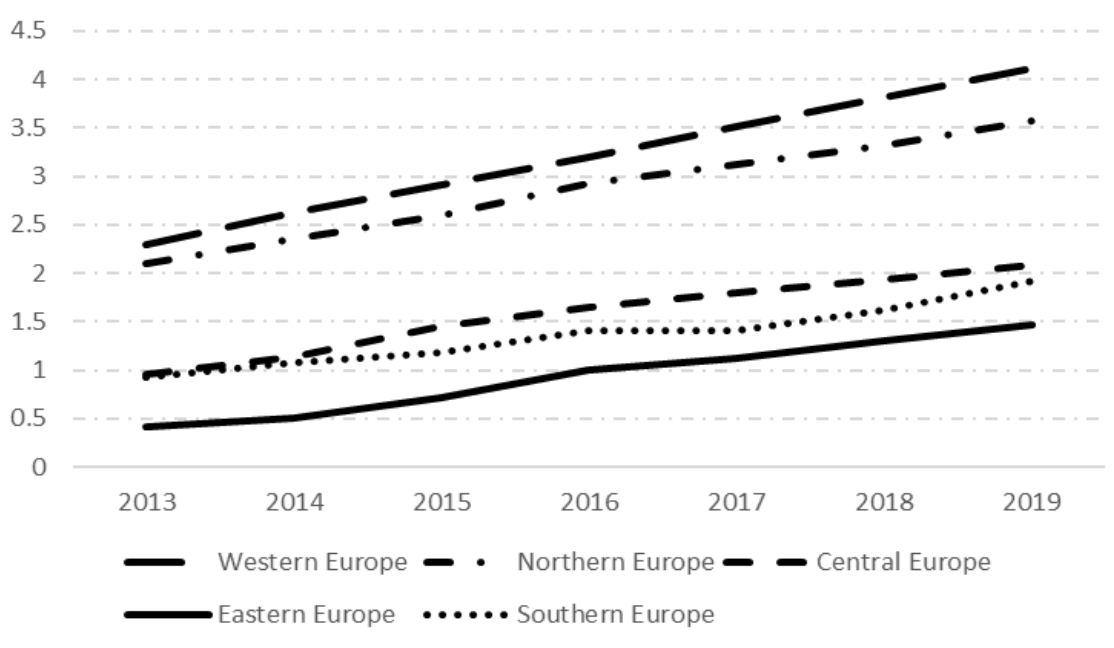

Figure 2. E-GDP (\%) by regions of Europe

Source: Data from Ecommerce Europe (2019) in collaboration with EuroCommerce and author's presentation

Sales revenues growth rates are calculated and compared at current prices in Division G.47 Retail trade, and in Class 47.91 - Retail sale via mail order houses or via Internet. Statistical data from NSI have been provided upon the author's request. The differences are significant: sales revenues from non-store retailing - orders by mail, telephone or Internet, for the period 2008 2018, have increased almost five times, whereas in retail in general - by $49.34 \%$.

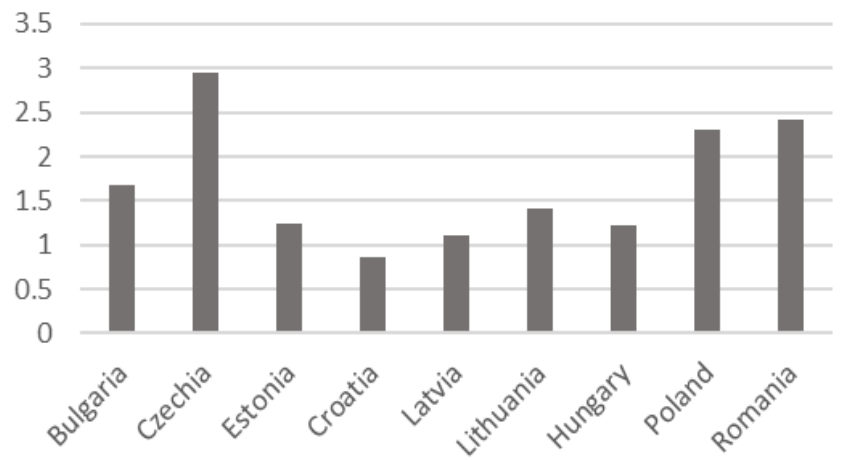

Figure 3. E-GDP by countries (\%)

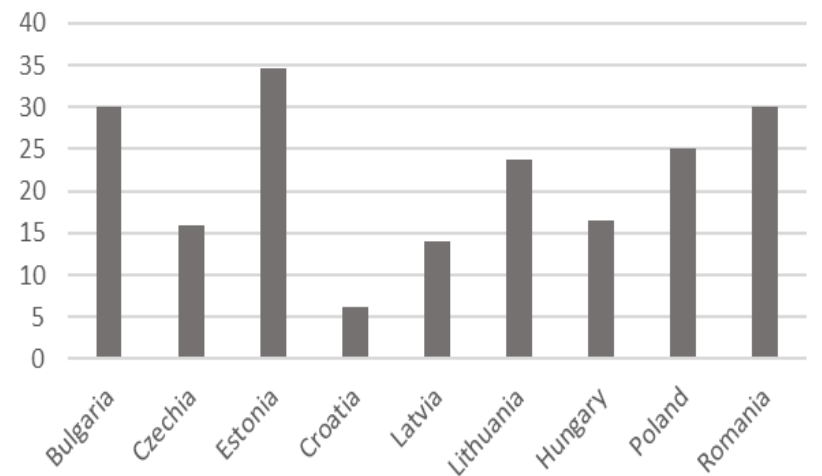

Figure 4. Turnover growth 2019 to 2013 (\%)

Source: Ecommerce Europe date (2019) in collaboration with EuroCommerce and author's presentation

E-commerce share is still a small part of total retail sales. However, a comparison of baseline growth rates through the outpace ratio (between retail, telephone or Internet retail growth rates and the total retail trade growth rates, in particular) is indicative of the development of electronic commerce as a driving force of growth in the retail sector. The indicator shows a continuous growth over the years throughout the examined period; all its values are $>1-$ from 1.06 in 2008 , to 3.19 in 2018.

Alongside the development of e-commerce, the sectors of information technologies and services are expanding as well, and it's a two-way street. The contribution of the ICT sector to the country's economy is expressed not only by its GDP share but by its influence on digitalisation 
processes in other economic sectors, mostly in trade. Eurostat data show that in Bulgaria the ICT sector has the highest GVA share in total GDP of $6.1 \%$, followed by Hungary with $6.05 \%$, and Lithuania $(3,15 \%)$ and Poland $(3,6 \%)$ with the lowest shares (Table 2.).

Table 2. Percentage of the ICT sector in GDP by countries of Central and Eastern Europe

\begin{tabular}{|l|c|c|c|c|c|c|c|c|c|c|}
\hline Countries & $\mathbf{2 0 0 9}$ & $\mathbf{2 0 1 0}$ & $\mathbf{2 0 1 1}$ & $\mathbf{2 0 1 2}$ & $\mathbf{2 0 1 3}$ & $\mathbf{2 0 1 4}$ & $\mathbf{2 0 1 5}$ & $\mathbf{2 0 1 6}$ & $\mathbf{2 0 1 7}$ & $\mathbf{2 0 1 8}$ \\
\hline Bulgaria & 4.85 & 4.86 & 4.64 & 4.57 & 4.72 & 4.89 & 5.05 & 5.38 & 5.72 & 6.1 \\
\hline Czechia & 4.44 & 4.39 & 4.34 & 4.35 & 4.34 & 4.27 & 4.24 & 4.27 & 4.36 & 4.56 \\
\hline Estonia & 4.95 & 4.74 & 4.98 & 4.66 & 4.57 & 4.79 & 4.7 & 4.85 & 5.11 & 5.38 \\
\hline Croatia & 4.08 & 4.62 & 4.05 & 3.9 & 4.12 & 4.07 & 4.2 & 4.22 & 4.4 & - \\
\hline Latvia & 3.4 & 3.54 & 3.29 & 3.46 & 3.73 & 3.75 & 4.18 & 4.6 & 4.73 & 4.92 \\
\hline Lithuania & - & 2.41 & 2.42 & 2.48 & 2.38 & 2.57 & 2.94 & 2.95 & 3.02 & 3.15 \\
\hline Hungary & 5.72 & 5.67 & 5.95 & 5.73 & 5.8 & 5.61 & 5.75 & 5.69 & 6.04 & 6.05 \\
\hline Poland & 3.06 & 3.19 & 3.27 & 3.12 & 3.01 & 3.05 & 3.15 & 3.22 & 3.33 & 3.6 \\
\hline
\end{tabular}

source: Eurostat

Revenue volume from trade services in retail and wholesale sectors, measured by the gross margin indicator, differs significantly from country to country depending on the scale of domestic demand. It is highest in Poland, followed by the Czech Republic and Romania. The general trend for the period 2009 - 2018 by country, shows an increase in the gross margin volume in the trade sectors, except for Croatia, where it decreased by $7.78 \%$. The highest index of revenue growth from trade services at current prices is in Lithuania (209.95\%), Estonia (208.66\%), Romania (203.36\%) and Latvia $(202,80 \%)$. Bulgaria ranks first in the second group of countries with a growth index of $176.08 \%$, followed by Slovenia (163.17\%), Hungary (156.32\%) and the Czech Republic (151.87\%).

Table 3. Gross margin on goods for resale as a part of turnover (\%)

\begin{tabular}{|l|l|l|l|l|l|l|l|l|l|l|}
\hline 4Countries & $\mathbf{2 0 0 9}$ & $\mathbf{2 0 1 0}$ & $\mathbf{2 0 1 1}$ & $\mathbf{2 0 1 2}$ & $\mathbf{2 0 1 3}$ & $\mathbf{2 0 1 4}$ & $\mathbf{2 0 1 5}$ & $\mathbf{2 0 1 6}$ & $\mathbf{2 0 1 7}$ & $\mathbf{2 0 1 8}$ \\
\hline Bulgaria & 12,87 & 12,21 & 11,72 & 11,71 & 12,20 & 13,10 & 13,47 & 13,65 & 13,68 & 14,13 \\
\hline Czechia & 14,54 & - & 14,40 & 14,00 & 13,72 & 13,95 & 14,38 & 15,09 & 14,47 & 15,85 \\
\hline Estonia & 15,25 & 14,55 & 13,66 & 14,22 & 13,74 & 13,90 & 14,93 & 15,68 & 14,91 & 15,34 \\
\hline Croatia & 26,38 & 19,28 & 18,50 & 17,87 & 18,14 & 19,17 & 19,53 & 20,10 & 20,13 & 20,37 \\
\hline Latvia & 16,69 & 15,24 & 14,41 & 14,88 & 14,35 & 15,35 & 15,67 & 16,66 & 17,20 & 17,40 \\
\hline Lithuania & 18,54 & 19,55 & 20,96 & 18,32 & 17,27 & 18,32 & 19,20 & 20,10 & 19,48 & 20,12 \\
\hline Hungary & 17,34 & 15,34 & 17,37 & 15,87 & 15,88 & 16,14 & 17,28 & 16,79 & 18,64 & 19,52 \\
\hline Poland & - & - & - & - & - & 11,39 & 11,52 & 11,80 & 11,67 & 11,82 \\
\hline Romania & 14,55 & 15,73 & 15,14 & 15,19 & 16,28 & 16,49 & 18,40 & 19,19 & 19,53 & 20,01 \\
\hline Slovenia & 13,87 & 15,54 & 16,96 & 15,18 & 15,88 & 15,03 & 15,99 & 16,77 & 16,55 & 16,44 \\
\hline Slovakia & 15,44 & 15,74 & 13,03 & 14,15 & 14,99 & 14,29 & 13,81 & 14,66 & 14,88 & 15,31 \\
\hline
\end{tabular}

source: Eurostat and author's calculations

The gross margin is used to measure the market power of the retail and wholesale industry. Differences in the levels of gross margin are mainly due to the structure of trade - wholesale and retail, differences in the concentration of the sector and its supply sectors respectively, as well as the consumers' buying power. For example (Table 3.), Croatia has the highest levels of gross margin during the period, which is related to the development of retailing as part of the tourist services. Poland and Bulgaria exhibit the lowest gross margin levels. For Bulgaria, the lower gross margin 
levels are due to the predominant share of wholesale trade in consumer goods. In 2018, its turnover exceeded retail grocery sales with $33,51 \%$. Over the period, the ratio between wholesale and retail sales of consumer goods decreased from $151.61 \%$ (2009) to $133.51 \%$ (2018). Among the reasons is the increased retail concentration, increased market shares of retail chains which buy directly from manufacturers and also perform the functions of wholesalers. In addition to that is the proliferation of e-commerce which also supports direct sales channels to end customers.

For Bulgaria, this indicator first decreased from $12.87 \%$ (2009) to $11.71 \%$ (2012), then gradually increased, reaching $14.13 \%$ (2018), which is higher than that at the beginning of the period. In Hungary, the commercial sector generally enjoys higher competitiveness: the gross margin level was $14.54 \%$ (2009), then decreased to $13.72 \%$ (2014), and began to recover again reaching $15.85 \%$ (2018).

The trend is similar in most Central and Eastern European countries. In most countries, the level of gross margin has been declining in the first years after the crisis, reaching its lowest levels in 1012 or 2013. The trend is explicable in terms of efforts to restore sales levels even at the expense of sharing income with supply chain partners, and especially with customers. It is worth noting the manifested exception in Romania, Slovenia and Hungary, where the gross margin level is at its lowest at the beginning of the period, then gradually increases until 2018. In Romania, the trend is particularly pronounced with an annual gross margin increase from $14.55 \%$ to $20.01 \%$.

Table 4. Number of persons employed in wholesale and retail trade by countries of Central and Eastern Europe $(2015=100 \%)$

\begin{tabular}{|l|r|r|r|r|r|}
\hline Countries & $\mathbf{2 0 1 5}$ & $\mathbf{2 0 1 6}$ & $\mathbf{2 0 1 7}$ & $\mathbf{2 0 1 8}$ & $\mathbf{2 0 1 8}$ \\
\hline Bulgaria & 100.0 & 100.3 & 101.2 & 99.8 & 100.3 \\
\hline Czechia & 100.0 & 99.8 & 99.7 & 100.6 & 102.6 \\
\hline Estonia & 100.0 & 103.3 & 105.6 & 106.3 & 108.5 \\
\hline Croatia & 100.0 & 100.8 & 101.0 & 100.9 & 100.2 \\
\hline Latvia & 100.0 & 100.3 & 98.5 & 97.8 & 99.1 \\
\hline Lithuania & 100.0 & 101.2 & 99.6 & 97.8 & 96.4 \\
\hline Hungary & 100.0 & 103.9 & 106.2 & 111.2 & 116.9 \\
\hline Poland & 100.0 & 101.8 & 105.5 & 107.0 & 108.6 \\
\hline Romania & 100.0 & 104.8 & 108.5 & 111.6 & 115.2 \\
\hline Slovenia & 100.0 & 101.6 & 104.2 & 106.5 & 108.4 \\
\hline Slovakia & 100.0 & 98.1 & 101.3 & 103.8 & 101.8 \\
\hline
\end{tabular}

source: Eurostat

Gross margin performance should be compared with employment performance in the sector. According to Eurostat (2017), almost half of employment in the European Union in 2016 was concentrated in two economic activities: "wholesale and retail trade, transport, accommodation and food services" (24.7\%), and "public administration, defence, education, human health and social work activities" (23.7\%). Trade sector, along with transport, accommodation and food services, occupy the largest share of total employment in most countries.

However, in most countries that have made the transition to a market economy, employment in the trade sector is difficult to recover. Hungary and Romania make an exception with increased employment levels by $16.9 \%$ and $15.2 \%$ respectively, in the last five years of the study period (Table 4.). In 2013, Bulgaria displayed the lowest number of employees in the trade sector with a total decrease of $10.55 \%$, after which employment slowly recovered. Nevertheless, in 2018 it could not reach the level of employment in the sector from 2009. There are different rates of employment recovery per country in the trade sector between the two economic crises. Employment rates recovered fastest in Hungary and Romania, followed by Poland, Estonia and Slovenia. 
The employment trend in class G 47.91 - Retail sale via mail order houses or via Internet, is radically different, according to NSI data processed by the author's request. The number of retail sales employees working in companies specialised in retail trade by mail, telephone or the Internet has increased by more than six times. Nonetheless, employees' productivity in this class of retail, calculated by sales revenue, remains well below the 2008 levels. In 2018, it was $75.61 \%$ of the level value at the beginning of the period. Productivity metrics based on gross margin per employee also show decreased productivity. Labour productivity is at its lowest in $2015-61.82 \%$, with 2008 levels as a baseline. It recovers to $95.66 \%$ in 2018 but is still well below the value in the first year of the studied period.

\section{Conclusion}

Our brief descriptive analysis supports the argument that e-commerce is a main source of growth in the retail sector. This is a common trend to all countries in the sample, regardless of differences in their trade sectors in terms of sales potential. The benefits associated with ecommerce such as expanded choice, reduced research and ordering time, and higher value for money, increase the marginal propensity to consume. The development of e-commerce in the period between the two economic crises is associated with the gross margin recovery, while the rapid expansion of e-commerce and hybrid forms of trade contribute in turn to the latter. The indicator demonstrates preservation of the market power of retailers regardless of the e-commerce growth and the opportunities for direct sales from manufacturers to end customers.

The high growth rates of employees in retail e-commerce is at the core of sales growth. Investigation on the productivity of companies specialised in e-retailing in Bulgaria demonstrates the so-called puzzle in the development of productivity: its values are maintained lower than those in the first year of the researched period. We observe a restructuring of the workforce and its steering to digital economy sectors aimed at expansion of the e-business market share. In addition, the performance of part of the distribution services by information services companies redirects GVA to other sectors of the economy. Digitalisation is blurring the boundaries between wholesale and retail trade, and between specific economic sectors.

Rising unemployment and declining propensities to consume, especially after 2020 crisis in the context of evolving Covid-19 pandemic, requires new options for productivity increase in wholesale and retail trade sector.

\section{References}

1. Betancourt, R. (2017) Distribution Services and the Digital Economy: Implications for GDP Measurement, Productivity and Household Welfare, pp.1-38 [online] Available to: file:///C:/Users/User/Downloads/Betancourt\%20\%20-\%20Distribution \%20Services\%20\%20\%20and\%20the\%20Digital\%20Economy.pdf [accessed 30/10/ 2020].

2. Couclelis, H. (2004), Pizza over the Internet: e-commerce, the fragmentation of activity and the tyranny of the region, Entrepreneurship \& Regional Development, 41-54.

3. Ecommerce Europe (2020) Collaborative Report on Sustainability and e-Commerce [online] Available to: https://www.ecommerce-europe.eu/wp-content/ uploads/2020/09/CollaborativeReport-on-Sustainability-and-e-Commerce.pdf [accessed 30/10/2020].

4. Ecommerce Europe in collaboration with EuroCommerce (2019) European Ecommerce Report [online] Available to: https://www.ecommerce-europe.eu/wpcontent/uploads/2019/07/European_Ecommerce_report_2019_freeFinal-version.pdf [accessed 28/10/2020].

5. EuroCommerce and UNI-Europa (2016) Analysis of the Labour Market in Retail and Wholesale [online] Available to: https://www.eurocommerce.eu/media/143280/ Labour_Market_Analysis_In_Retail_And_Wholesale_Full_Version.pdf [accessed 27/10/2020]. 
6. European Commission (2015) Retail Competitiveness. Report of the Preparatory Working Group on SMEs [online] Available to: file:///C:/Users/User/Downloads/high-levelcompetitiveness-report-sme-v1\%20(1).pdf [accessed 27/10/2020].

7. Eurostat (2017) Which sector is the main employer in the EU Member States? [online] Available to: https://ec.europa.eu/eurostat/web/products-eurostat-news/-/DDN-20171024-1 [accessed October 15 2020].

8. McKinsey\&Company. The Rise of Digital Challengers. How the Digitalization can Become the New Growth Engine for Bulgaria and Central and Eastern Europe, 2017 [online] Available to: https://digitalchallengers.mckinsey.com/files/

McKinsey_Digital\%20Challengers_Perspective_on_Bulgaria_online.pdf [accessed 15/08/2020].

9. Moriset, B. (2020) The Geography of E-Commerce. Barney Warf. Geographies of the Internet, Routledge, 2020, Routledge Studies in Human Geography. [Online] Available from: https://halshs.archives-ouvertes.fr/halshs-01937098/document [Accessed 22/10/2020].

10. National Statistical Institute, Bulgaria, https://www.nsi.bg/.

11. Office of National Statistics, UK (2015) What is the productivity puzzle? [Online] Available from: https://www.ons.gov.uk/employmentandlabourmarket/ peopleinwork/labourproductivity/ articles/whatistheproductivitypuzzle/2015-07-07 [Accessed 23/10/2020].

12. Porter, M. (1998) Competitive Strategy: Techniques for Analyzing Industries and Competitors, New York, The Free Press.

13. Profit.bg (2019) 15000 Elektronni magazine deklarirani v NAP [Online] Available from: https://profit.bg/balgariya/15000-elektronni-magazini-deklarirani-v-nap/

[Accessed 22/10/2020].

14. United Nations (2020) Economic and Social Challenges and Opportunities. A Compilation of the United Nations High-level Advisory Board on Economic and Social Affairs. Published by the United Nations, Department of Economic and Social Affairs New York, New York 10017, United States of America [Online] Available from: https://www.un.org/ development/desa/en/wp-content/uploads/2020/07/ RECOVER_BETTER_0722-1.pdf [Accessed 22/10/2020]. 